\title{
Rapunzel In Developing Economy: A Study About Relationship Between Globalization And Women Workforce Issues In Pakistan
}

\author{
Roohi Mumtaz \\ Syed Shabib ul Hasan \\ Afsheen Nizam \\ \& \\ Saima Akhter \\ Department of Public Administration \\ University of Karachi
}

\begin{abstract}
As the globalization is bringing change in the business scenarios, there is a need to bring change in the mindset, beliefs, attitude and performance to bring change in the lives of the people. By definition globalization is the multifaceted financial, supporting, civilizing and the geographical development through which the flow of money, companies, innovative approach, talks and the employees have taken a transitional change. Women in third world economies are generally confined under social, cultural, religious and economic boundaries where they are not be allowed to utilize their true potentials and prosper. Under such suppression, businesses mostly prefer female labour, as they remain cheaper and obedient. The paper focuses on the relationship between globalization and the women work force issues in Pakistan. The study also highlights the impact of discriminatory acts like gender discrimination, gender employment segregation and financial biasness in Pakistani society. The findings reveal that discrimination and double standards in the society for women is very common and prevail, more obviously in Pakistan. There is a need to eliminate all the discriminatory elements from the mindset by taking visionary steps in the right direction.
\end{abstract}

Key Words: Pakistan, Female Workforce, Globalization

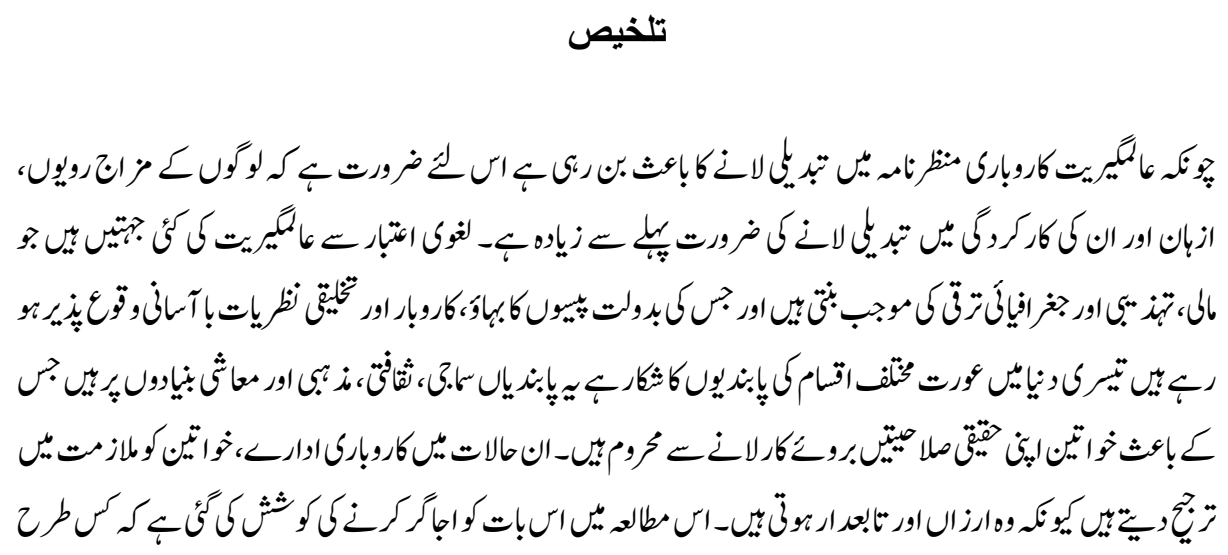




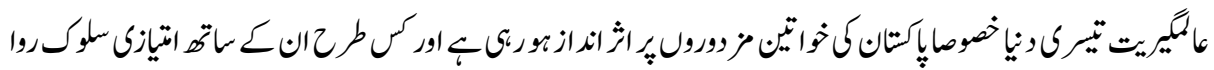

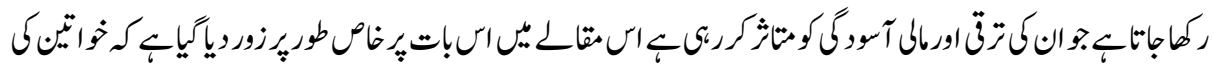

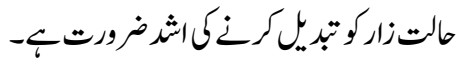

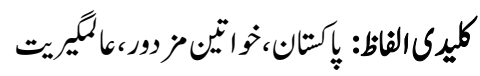

\section{Introduction}

Globalization in fact provides plenty of prospects to women all around the world to make money for their livelihoods with great ease, however in Pakistan; the impact of globalization is not much successful due to the overall socio-economic condition. Unfortunately women did not get many chances as they could have in other countries of the region. The situation and working conditions are entirely different and narrower as the restrictions on the women for being a Muslim woman are severe from those of the other neighbouring countries. This is an exposed truth that women mostly used but have no legal rights or platform to raise their voices against the social injustices. The government usually supports the management to flourish instead of supporting their workers, as they are the victims of very often violations of the labour laws. Although with the Globalization level of opportunities to work and flourish have increased but women are still being suppress at every level with respect to employment segregation, indifference wage system and women trafficking.

Women participation has increased as a labour workforce in different industries formally and informally but in spite of these increase opportunities redundancy increases with much rapid pace and poverty prevails within them even more severely. In the rural areas of Pakistan, the rate of unemployment and gender disparity element is much harsher than urban areas and the opportunities for women remains minor and restricted. Gender inequality is very common in developing economies but in Pakistan worse picture of the gender indifferences can easily be seen, where in the name of religion; social and moral values, many obligations imposed on women to suppress their skills and abilities as much as possible. Another factor that matters much is the gender employment segregation. Women suffers severe gender employment inequality during her career as management often wanted the women workforce to participate in production process because they usually accept to work in working condition, not suitable for their good health.

Women all over the world are the sufferers in terms of lesser salary packages compared to men for the same category and post. This creates a huge gap among the genders and further opens sense of gender in security. Furthermore, management 
place their interests and benefits over the workers working day and night for them and still live under poverty line (Harper and Leicht, 2002). Some studies also provide data that the offered salaries to female workers are insufficient as they are considered too weak to raise their voice. As women, do not have unions, laws to safeguard their rights and platform to raise their voices against the discrimination being done with them. They paid specifically low salary and low or insufficient benefits that fail to cover their basic needs and requirements of daily life (Fuentes and Ehrenreich, 1998). The most significant among them all is the matter of aggression and abusive behaviour against women which needs to be controlled and eliminated. Furthermore, trafficking of young girls and women has become major concern over the years. It is estimated that about two hundred twenty five thousand of girls and women from South East Asia alone are trafficked every year, which constitutes about one-third of the global trafficking business.

\section{Globalization through Feminine Lens}

In conditions of global entrepreneurial society wants methodically convert into needs and pushes the simple society into entrepreneurial and defines the principles and morals of Globalization. As the global scenario changed with the businesses crossing borders, the noticeable change also being observed in policies, procedures, environment and mind set related to all sectors whether formal or informal. People have enough opportunities available to set up small and innovative manufacturing business with more supple organization and very ordinary building in third world economy. Developed countries tried to setup their businesses in the countries where low costs and cheap labourers were easily available. Countries like China, Thailand, India, Bangladesh and Pakistan, are rich in human resources, not only men but also the women labourers are easily available. However management mostly prefer to hire female workers because not only they are cheaper than men but also because they accept given jobs with no rights, no security and with no organized forms of unions to raise voices against any injustices management made against them.

Since, most of the women in Pakistan are illiterate or do not have superior qualification, they are more inclined towards informal or secondary sector where skills and education does not matter much. They are treated as inferior labours compared to male workers and be given working conditions not suitable for their health. There is hardly any system present in order to evaluate their work. No checks and balances regarding work is present that is why their work gets tougher and tougher day by day with very lengthy and tough hours with nominal mode of payments.

On the pretext of Globalization, management exerts immense pressure on the women workers to work hard for their survival despite facing lack of attention, food, cloth 
and other necessities of life. These make threats to their life and health and also adversely affect their next generation as well. They are simply leading a life of ignorance, tolerance and hardship for so many means. These indicators are especially worrisome for Pakistan because they have least gender development signs as compared to the other countries of the region. Reports on the human development reveals that the female financial activity in Pakistan is at the least level and joblessness rates are at the top level in comparison to that of the other countries in the region.

The trends of women participation as a workforce labour and the impact of globalization on them are pessimistic. Formal and informal sector's disparity has great impact on the lives of the women in Pakistan. The pressure of population influx to the urban areas for jobs and better prospects of living increases with the passage of time. Therefore, there is a need to plan and formulate policies with respect to socioeconomic development, maintained at both urban and rural areas.

\section{Table: 1}

\section{Percentage Distribution of Population 10 Years of Age and Above by Sex and Area} 2003-2004

\begin{tabular}{|l|l|l|l|}
\hline Country/Area & Total & Male & Female \\
\hline Pakistan & 100.00 & 50.86 & 49.14 \\
\hline Rural & 64.22 & 32.37 & 31.86 \\
\hline Urban & 35.78 & 18.50 & 17.28 \\
\hline
\end{tabular}

Source: Statistics Division, Federal Bureau of Statistics. Labour Force Survey 2003-2004

According to 2003-04 survey table of population distribution given above there were total $50.84 \%$ of male population in Pakistan, out of which $32.37 \%$ were living in rural and $18.50 \%$ in urban areas. Females were $49.14 \%$ of the total population out which $31.86 \%$ were living in rural and $17.28 \%$ in urban areas. 
Table: 2

Refined (and Improved) Labour Force Participation Rates: Provinces and Area

\begin{tabular}{|l|c|c|c|c|c|}
\hline \multirow{2}{*}{ Province Area } & Total & Male & Female & \multicolumn{2}{|c|}{ Improved-04 } \\
\cline { 5 - 6 } & & & & Total & Female \\
\hline Pakistan & $\mathbf{4 3 . 7}$ & $\mathbf{7 0 . 6}$ & $\mathbf{1 5 . 9}$ & $\mathbf{5 5 . 3}$ & $\mathbf{3 9 . 3}$ \\
\hline Rural & 46.3 & 72.6 & 19.5 & 62.9 & 52.7 \\
\hline Urban & 39.2 & 67.1 & 9.4 & 41.7 & 14.5 \\
\hline Balochistan & $\mathbf{4 0 . 0}$ & $\mathbf{6 8 . 1}$ & $\mathbf{7 . 6}$ & $\mathbf{5 6 . 4}$ & $\mathbf{4 2 . 6}$ \\
\hline Rural & 42.0 & 71.5 & 8.2 & 62.6 & 52.1 \\
\hline Urban & 34.0 & 58.1 & 5.9 & 37.8 & 14.0 \\
\hline Khyber Pakhtunkhwa & $\mathbf{3 7 . 2}$ & $\mathbf{6 5 . 7}$ & $\mathbf{1 0 . 2}$ & $\mathbf{5 7 . 7}$ & $\mathbf{5 0 . 0}$ \\
\hline Rural & 37.5 & 66.0 & 10.8 & 61.1 & 56.2 \\
\hline Urban & 35.7 & 64.3 & 7.1 & 41.4 & 18.5 \\
\hline Punjab & $\mathbf{4 7 . 0}$ & $\mathbf{7 1 . 8}$ & $\mathbf{2 1 . 8}$ & $\mathbf{5 5 . 0}$ & $\mathbf{3 7 . 8}$ \\
\hline Rural & 49.9 & 73.6 & 26.4 & 61.1 & 48.5 \\
\hline Urban & 41.0 & 68.5 & 12.3 & 42.8 & 16.0 \\
\hline Sindh & $\mathbf{4 0 . 5}$ & $\mathbf{7 0 . 8}$ & $\mathbf{6 . 6}$ & $\mathbf{5 4 . 5}$ & $\mathbf{3 6 . 1}$ \\
\hline Rural & 43.6 & 75.8 & 7.4 & 70.5 & 64.3 \\
\hline Urban & 37.8 & 66.4 & 5.9 & 40.6 & 11.7 \\
\hline
\end{tabular}

Source: Statistics Division, Federal Bureau of Statistics. Labour Force Survey of Pakistan 2003-2004:127-131.

The agricultural labour force were more accurately redefines women's economic participation thus when reports were gathered, amazingly their participation has now shown much higher figure than ever. As they work with least rights, at comparatively low price and mostly on contractual basis, their exact data of participation in informal and formal sector is a bit difficult task to sort out. Women's other imperceptible job like giving birth and household work remains countless (Mahboob-ul-Haq, Human Development Centre 2000: 53).

Table: 3

Distribution of Workers in Industry by Gender (percent)

\begin{tabular}{|l|l|l|l|l|}
\hline & \multicolumn{2}{|c|}{ Rural } & \multicolumn{2}{c|}{ Urban } \\
\hline & \multicolumn{1}{|c|}{ Male } & \multicolumn{1}{c|}{ Female } & \multicolumn{1}{c|}{ Male } & Female \\
\hline Agriculture & 53.8 & 76.9 & 5.3 & 9.4 \\
\hline Other Services & 13.2 & 10.6 & 27.6 & 57.5 \\
\hline Manufacture & 6.6 & 11.2 & 20.2 & 27.1 \\
\hline Construction & 10.0 & 0.2 & 6.7 & 0.6 \\
\hline Trade & $\mathbf{9 . 9}$ & 1.0 & 27.1 & 4.3 \\
\hline Transport & 5.6 & 0.0 & 11.1 & 0.8 \\
\hline
\end{tabular}

Source: Estimates using Pakistan Integrated Housing Survey 2001-2. (World Bank 2006: 89) 
The Pakistan Integrated Housing Survey has given the data above in shown in Table 3 that highlights the dispersion of employees by the industry. It is obvious from the facts given in the data above that women are more focus towards agriculture in rural areas despite the fact that women in urban centres have more diverse range of opportunities available. Cottage industries and informal sectors provide a variety of work from embroidery to sewing and from running tuition institute to cooking and baking centres. The only industry that shows some improvement and expansion of jobs in Pakistan and provides better opportunities to women according to the Labour Force Survey 2003-04 is in the category of "skilled agriculture and fishery". The growth shows an increase from $48.4 \%$ in $2001-02$ to $52.8 \%$ in 2003-04 (Mumtaz 2005:36).

Women from civil society in Pakistan have always insisted for the time-use surveys for women as the time-use statistics would give a clear picture of the contribution made by women as a labour workforce in the metropolitan informal sector where females are mostly engage in industrialized and household job (Kazi 1999: 385, 390-2, Shaheed and Mumtaz 1990). It is also suggested that the agricultural and domestic workers should be brought into the legal framework so that they can avail their rights and contribute with motivation in the economic uplift of the economy.

Although women contribution as labour in different disciplines have increased but it could be observed that unemployment rate among them have also increased. In 2003-04, $12.75 \%$ of women were jobless which is much higher than $5.65 \%$ unemployed men. The disparity of gender and redundancy rate of females is harsher than males in urban areas. The rate is $19.82 \%$ for females and $8.38 \%$ for males (statistic division 2004: 127). The opportunities for women remain restricted to agricultural, services (domestic), and minorsize industries (Siddiqui et al 2006a: 178-9).

Contributions from females' workforce in rural areas have augmented agricultural productivity contributions. The increase agriculture productivity has lead to the increase opportunities for female workers to avail them (Kazi 1999: 387). The reason for growth of female worker is the migration of male workers to the urban areas. According to the labour force survey, around $73 \%$ of women in the rural areas are having job in the informal sectors other than agriculture. Their revenues mostly generated from the domestic animals and their products, on-farm labour, home-based income, other activities like piece rate job, brick laying work and household services.

The invisibility of women's work in Pakistan is common despite attempts being made towards making their efforts visible (Kazi 1999:391). Lack of facts and figures contributes towards the obstacle of women economic empowerment planning. Efforts have been made to empower women but the situation still not much improved. 


\section{Gender Employment Segregation}

Gender employment segregation is also a significant issue for women's career. Although management usually want women to work for them, but only because these women work in conditions where the men demands much higher wages. Women would even work in condition not suitable for their health without raising voices against it. Women work there, despite the fact unions would not authorize the place suitable for work, at low wages just to bring some relief in their livelihood. (Moghadam 1999). These women are fascinated towards this kind of work because they have no or less opportunities available. Women in Pakistan are clearly subject to higher gender employment segregation in comparison to males and offered much inferior posts and positions with relatively low compensation than males for the same discipline. This discriminatory attitude against women is not only common in third world poor countries but also very common in the rich, civilized and developed one.

Comparison between the occupations reveals that about two-third of the women workers, working at the lower level labourers while female workers able to work on the managerial and administrative posts are marginal (Tzannatos 1998). Firms that strengthening women subordinates in their organizations, offering them lower or inferior posts along with the low compensation packages in comparison to men. In Pakistan, these female workers always being hesitant, working in male dominating departments, divisions or sections. They feel quite difficult to work freely, independently, and ultimately suffered a lot, work wise. Managements are not willing to afford these kinds of problems in their organizations, so women offered and employed in very limited areas and sections in Pakistan and that ultimately narrow down their chances of getting better jobs, positions, wages and benefits. Only school management in Pakistan mostly prefer female staffs and teachers because of the fact they can easily be handled accordingly. They normally agree and accept much less benefits and salary packages than males.

\section{Gender Discrimination}

With increased Globalization, the world has become a global village, but gender discrimination still exists in every society as a major threat. Many countries around the world have attained success with Globalization and have gained strength socially, culturally and economically. However, a bitter reality of Globalization is the increase level of gender inequality. It is a brutal fact of Globalization that the workers in third world countries living below the poverty line. Instead of getting sufficient earning in return of hard work done, these workers can get only get meagre amount to live up their life with great difficulties. Among these poor workers majority are the women workers, who become the prey of their employer as well as their own people. As 
managers or supervisors are mostly men, never allows female to rise up the hierarchy within the managerial system. The culture of gender discrimination and wage difference is very common in our society as if any one succeeded to become a manager or supervisor with her own efforts, they create every possible hindrance and problems in her way of success.

Since Pakistan and its neighbouring countries have generally attained low fiscal development rate over the last two decades, the region lags apart compared to other regions of the world in terns of societal indicators. The indicators of gender related issues are even worse in Pakistan (Common wealth secretariat 1991; Elson 1992; Ghosh 1993; UNDP 1995). In Pakistan, women comparatively get significantly low salary with least benefits, slightest chance to compete and minimal opportunities to grow despite being on the priority list of government scrutiny than those of men. The inference of the cheap earnings and wages by these women and their benchmark of livelihood put on extra load of the work on their shoulders and have not being paid sufficiently for. (Ghosh 1999)

Although, it is believed that Globalization has provided women some freedom but they are not allowed to raise the similar kind of managerial level as do by men. In fact, most of the managers think that garment assembling work and same pattern of work would be more suitable for these women as they believe it is an extension of their household work. These limited visions of the managers, do harsh against women. They stigmatized by their superiors as a labour instead of having promotion to supervisors and managers. These females are captive to the position they are working at because of the gender element and anticipations. Working women have to play two roles simultaneously in order to survive. They have to facilitate and sustain these roles devoid of the reliance on their counterparts' support. Even jobless males reject to contribute in the casual work of their counterparts (Ward 1990).

Handling the matters of women workforce could not be a difficult task under the guidance of clear-cut objectives of ILO's Equal Remuneration Convention 1951 (No. 100) to authenticate the women grievances against equal pay of equal value of work. Moreover, the gender biasness against women with respect to race colour social cultural and political opinion and origin are required to eliminated at all levels of employment under ILO's Tripartite Declaration of Principles concerning Multinational Enterprises and Social Policy or The United Nations' Global Compact Project (Lozano and Boni, 2002). If women are given fair chances and abide some of the restrictions to prove themselves, they surely prosper their life towards betterment. 


\section{Financial Biasness}

Financial biasness and indifference of wage system is also one of the key factors of concern for Pakistani women. The fundamental labour rights address the issues that relate directly to the labour and their grievances. The incidence of having financial biasness and forced or compulsive work against women are also be the main issues under the labour rights to handle. The biasness against female worker is not just the issue of jobs and professions but also the fact that they must be given proper and equal opportunities to have far-reaching development in their careers and for this empowerment of women is the best option amongst all for their development and growth (Abu Ghaida and Klasen, 2004).

Women's wage in Pakistan is significantly low in comparison to that of males here even at the domestic level. Many cottage industries established in homes and run mainly by women by skilful capabilities but poorly paid by the contractors especially in rural areas. They assigned work for them through different sources and as these women hardly have any knowledge and worth of their work and skill. The strict societal and religious restrictions limit their advancement economically and these contractors took up majority of their skill's benefits. Furthermore, the sex based inequality and economic disparity is obvious from the opportunities these women get, in order to enhance their skills, abilities and talents and this is not all but in the primary vicinity of nutrition, health and endurance, the disparity seen as well in the allocation of chances for contribution in societal and pecuniary life. Given below are the charts of wage distributions of the males and females in Pakistan according to the labour force survey 2008-09 with respect to provinces, urban and rustic areas.

Percentage Distribution of Employee by Monthly Payments, Gender\& Provinces 2008-09.

\begin{tabular}{|c|c|c|c|c|c|c|}
\hline \multirow{2}{*}{$\begin{array}{c}\text { Province } \\
\text { (Rural) }\end{array}$} & \multicolumn{6}{|c|}{ Employees by Monthly Payments } \\
\hline & $\begin{array}{c}\text { Total } \\
\text { Employees }\end{array}$ & $\begin{array}{l}\text { Up to } \\
1500\end{array}$ & $\begin{array}{l}\text { Rs. } 1501 \\
\text { to } 2500\end{array}$ & $\begin{array}{l}\text { Rs. } 2501 \\
\text { To } 4000\end{array}$ & $\begin{array}{l}\text { Rs. } 4001 \& \\
\text { Over }\end{array}$ & $\begin{array}{c}\text { Average Monthly } \\
\text { Payments }\end{array}$ \\
\hline \multicolumn{7}{|c|}{ Both Genders (over 10 years Age) } \\
\hline Pakistan & 100 & 6.78 & 9.95 & 19.93 & 63.34 & 6422.79 \\
\hline Punjab & 66.12 & 5.56 & 7.84 & 13.8 & 38.92 & 6059.97 \\
\hline Sindh & 13.65 & 0.48 & 1.2 & 3.26 & 8.71 & 6889.62 \\
\hline K.P. & 16.01 & 0.67 & 0.82 & 2.49 & 12.03 & 6982.66 \\
\hline Balochistan & 4.22 & 0.07 & 0.08 & 0.39 & 3.68 & 8471.4 \\
\hline \multicolumn{7}{|l|}{ Male } \\
\hline Pakistan & 86.29 & 3.13 & 5.57 & 17.25 & 60.34 & 6849.7 \\
\hline Punjab & 53.89 & 2.07 & 3.75 & 11.52 & 36.55 & 6630.24 \\
\hline
\end{tabular}


234 Rapunzel in Developing Economy: A Study about Relationship between Globalization and Women Workforce Issues in Pakistan

\begin{tabular}{|c|c|c|c|c|c|c|}
\hline Sindh & 13.07 & 0.43 & 1.03 & 3.07 & 8.54 & 6996.27 \\
\hline K.P. & 15.24 & 0.56 & 0.72 & 2.31 & 11.65 & 7049.6 \\
\hline Baluchistan & 4.1 & 0.07 & 0.08 & 0.35 & 3.6 & 8525.35 \\
\hline \multicolumn{7}{|l|}{ Female } \\
\hline Pakistan & 13.71 & 3.64 & 4.38 & 2.68 & 3 & 3735.13 \\
\hline Punjab & 12.23 & 3.49 & 4.1 & 2.28 & 2.36 & 3546.74 \\
\hline Sindh & 0.58 & 0.05 & 0.18 & 0.19 & 0.17 & 4501.47 \\
\hline K.P. & 0.77 & 0.1 & 0.11 & 0.17 & 0.39 & 5655.73 \\
\hline Baluchistan & 0.13 & - & - & 0.04 & 0.08 & 6729.53 \\
\hline
\end{tabular}

Source: Pakistan Bureau of Statistics (labour force survey 2008-09)

Percentage Distribution of Employee (Monthly Payments, Gender\& Provinces) 2008-09.

\begin{tabular}{|c|c|c|c|c|c|c|}
\hline \multirow{2}{*}{$\begin{array}{c}\text { Province } \\
\text { (Urban) }\end{array}$} & \multicolumn{6}{|c|}{ Employees by Monthly Payments } \\
\hline & $\begin{array}{c}\text { Total } \\
\text { Employees }\end{array}$ & $\begin{array}{l}\text { Up to } \\
1500\end{array}$ & $\begin{array}{l}\text { Rs. } 1501 \\
\text { To } 2500\end{array}$ & $\begin{array}{l}\text { Rs. } 2501 \\
\text { To } 4000\end{array}$ & $\begin{array}{l}\text { Rs. } 4001 \\
\& \text { Over }\end{array}$ & $\begin{array}{l}\text { Average Monthly } \\
\text { Payments }\end{array}$ \\
\hline \multicolumn{7}{|c|}{ Both Genders (over 10 years Age) } \\
\hline Pakistan & 100 & 4.87 & 6.04 & 13.78 & 75.32 & 9040.89 \\
\hline Punjab & 52.43 & 3.3 & 4.04 & 7.53 & 37.55 & 8355.85 \\
\hline Sindh & 38.86 & 1.3 & 1.58 & 5.17 & 30.81 & 9873.28 \\
\hline K.P. & 6.06 & 0.23 & 0.38 & 0.85 & 4.61 & 8993.04 \\
\hline Baluchistan & 2.65 & 0.04 & 0.04 & 0.23 & 2.34 & 10494.86 \\
\hline \multicolumn{7}{|l|}{ Male } \\
\hline Pakistan & 88.04 & 2.68 & 3.85 & 12.12 & 69.39 & 9301.93 \\
\hline Punjab & 44.64 & 1.53 & 2.27 & 6.48 & 34.36 & 8766.38 \\
\hline Sindh & 35.49 & 0.96 & 1.23 & 4.69 & 28.61 & 9929.17 \\
\hline K.P. & 5.43 & 0.15 & 0.32 & 0.75 & 4.21 & 9036.01 \\
\hline Baluchistan & 2.48 & 0.04 & 0.03 & 0.2 & 2.2 & 10546.3 \\
\hline \multicolumn{7}{|l|}{ Female } \\
\hline Pakistan & 11.96 & 2.19 & 2.2 & 1.65 & 5.93 & 7119.42 \\
\hline Punjab & 7.79 & 1.77 & 1.77 & 1.05 & 3.19 & 6003.83 \\
\hline Sindh & 3.37 & 0.33 & 0.35 & 0.48 & 2.2 & 9284.55 \\
\hline K.P. & 0.63 & 0.08 & 0.07 & 0.1 & 0.39 & 8621.58 \\
\hline Baluchistan & 0.17 & - & 0.01 & 0.02 & 0.14 & 9751.67 \\
\hline
\end{tabular}

Source: Pakistan Bureau of Statistics (labour force survey 2008-09)

The table above clearly shows the uneven distribution of wage for the same kind of work between males and females. There is a vast difference observed as far as distribution of jobs and payments are concerned for the same level and category. In urban areas of Pakistan, the total number of both the sexes for $100 \%$ of employees 
earned approx Rs 9040.89 , out of which $88.04 \%$ are males and $11.96 \%$ are female employees working at different level and for different industries of Pakistan. Male employees get around Rs 9301.93 and female workers get payments around Rs 7119.42. The difference of payments scale and their participation help to understand the level of opportunities available for both the sexes in Pakistan and the prospects for future growth.

\section{Darkest Side}

Business of sex using young girls and women is very often considering a source of easy earning of money around the world but it is lustre over as a non-concern. Females related to prostitution are under the contractors who arrange the tours across the globe. These females involve to this profession, not only by their will but also by the economic condition of their families. Women who are involved to this profession are mostly prospering financially and become the source of encouragement to other women as well to join them, as it is the harvest fruit of globalization as well. These females are more organize in the far eastern countries than the females attach to this profession in India, Bangladesh and Pakistan. Mostly the contractors here took advantage of these poor women and young girls, and they sell them in favour of huge amount of money. In these women, mostly young aged kidnapped by the people involved to this profession and sent them to Middle East and Europe, to maximize their business. Nowadays this illegal trafficking of women takes advantages of all the modern technologies and techniques to gain more people towards them and sites of social networking is viably in use all over. As they grow older and older, their lives become more difficult and miserable. The women involved have greater chances to become the prey of deadly HIV/AIDS. The deaths of women infected by the disease are increasing. It is estimated that about two hundred thousand to two hundred twenty five thousand of girls and women from south East Asia trafficked every year and this figure indicating of about one-third of the global trafficking business. Having Islamic ideology, unfortunately this business also flourishes in Pakistan. The girls and women, who are the prey of this international business, smuggle to other countries and are more at stake of being sufferer, to other kind of aggression as well. These women became the carriers of unwanted pregnancy and deadly and sexually infected diseases like HIV/AIDS (IOM 2000). This tragedy with young women and girls with or without their will must be given attention and abide the severe after effects of illegal trafficking, that not only contaminate and poisoning the women but the whole society silently. 


\section{Conclusions and Recommendations}

With the rise of Globalization concept, the world becomes a global village. However, despite having seen economies grew socially, culturally and economically but unfortunately, it's a bitter reality that Globalization has not eliminated discrimination despite the growth of businesses and financial system around the world. Modern women has to confront enhanced challenges in the Globalization era and Pakistani women, are no exception as they have to encounter great amount of insecurities due to increased competition, sexual harassment, gender and opportunities inequalities.

Social and economic wellbeing and empowerment of women could never be materialize unless society takes the challenge and destroy the fort of male hegemony and allow women to have their true share life. There is a strong need to improvise the policies and legislations to safeguard women socio-economic right. The legislators have the strong responsibility to take initiative in designing particular action programs aimed at putting in place required legislation to empower women and eliminate all kinds of inequalities and disparities to ensure maximum admittance of productive resources towards contributing to socio - economic progress. Furthermore such environment would allow women to explore their true potentials and feel pride in utilizing the potentials for their betterment in a conducive and equitable environment.

It has also been found that propagation of the rewards of globalization to women in Pakistan in difficult because mostly they are ignorant about the value of their skills and potentials as education is a rare commodity for them. Since these women are unable to understand and decide about themselves, it is crucial to introduce a variety of advanced and basic practical literacy courses for women at the grass root level to help them handle the risk and rewards associated with globalization.

All the above changes require elimination of male chauvinism from the society and it could not be possible without the support of the men in society. It is also required that males must understand and share the work load provided women in the family are facing work overload. It requires that men recognize where the women of their family is standing and help them in identifying their true selves so they could be more productive and bring home prosperity. Needless restrictions, unjust practices, indifferent gender preferences, financial biasness and excessive duties on women would not serve women, family or economy any good. This is high time to realise the gravity of the issue and the society must make arrangement that every member of the society feels a part of it and understand what they have to contribute towards demolishing the walls of discrimination, and bigotry against the princess of the world. 


\section{References}

Abu-Ghaida, D. \& S. Klasen (2004). The Costs of Missing the Millennium Goals on Gender Equity', World Development, 32, 7, pp. 1075-107.

Elson, Diane. 1992. "From Survival Strategies to Transformation Strategies: Women's Needs and Structural Adjustments." in Unequal Burden: Economic Crises, Persistent Poverty and Women's Work, Lourdes Beneria and Shelley Feldman, editors. Boulder, CO: Westview Press, pp. 26-48.

Fuettes, Annette \& Barbara Ehenreich. (1998). Women \& the Global Factory Boston: South End Press.

Ghosh, J., (1993). Gender Concerns in Macroeconomic Policy, Economic and Political Weekly, April UNDP, 1995. Human Development Report 1995: Gender and Human Development (New York, Oxford University Press).

Ghosh, J., (1999). Impact of Globalization on Women: Women and Economic Liberalization in the Asian and Pacific Region.

Harper, Charles. \& Leicht, Kevin (2002), Exploring Social Change: America and the World, 4th ed. Upper Saddle River, N.J: Prentice Hall.

IOM, (2000). Combating Trafficking in South-East Asia: A Review of Policy and Programme Responses (Geneva, IOM) www.iom.int/documents/publication/en/ mrs_2_2000.pdf 12 March 2002.

Kazi, Shahnaz, (1999). Gender Inequalities and Development in Pakistan, in Shahrukh Rafi Khan, ed. 50 Years of Pakistan's Economy: Traditional Topics and Contemporary Concerns. Karachi: Oxford University Press, pp. 376-414.

Lozano, J. F. and A. Boni (2002). The Impact of the Multinational in the Development: An Ethical Challenge', Journal of Business Ethics, 39, 1-2, pp. 169-78.

Mahbub ul Haq Human Development Centre, (2000), Human Development in South Asia: The Gender Question 2000. Karachi: Oxford University Press.

Moghadam, Valentine M. (1999). Gender and Globalization: Female Labor and Women's Mobilization.” Journal of World Systems Research 2: pp. 367-388.

Mumtaz, Khawar. November, (2005). Gender and Poverty in Pakistan, Islamabad: Asian Development Bank. 
238 Rapunzel in Developing Economy: A Study about Relationship between Globalization and Women Workforce Issues in Pakistan

Pakistan Bureau of Statistics (labour force survey 2008-09)

Pakistan Integrated Housing Survey 2001-2. (World Bank 2006: 89)

Shaheed, Farida \& Khawar Mumtaz. (1990). Women's Economic Participation in Pakistan, Status Report for UNICEF Pakistan. Islamabad: UNICEF.

Siddiqui, Rehana., Shahnaz Hamid, Rizwana Siddiqui, Naeem Akhtar \& G.Y. Soomro. (2006a). Gender and Empowerment: Evidence from Pakistan. Islamabad: Pakistan Institute of Development Economics.

Statistics Division (Federal Bureau of Statistics). (2004). Labour Force Survey 20032004 Twenty fourth Issue. Islamabad: Government of Pakistan.

Statistics Division, Federal Bureau of Statistics. Labour Force Survey 2003-2004

Statistics Division, Federal Bureau of Statistics. Labour Force Survey of Pakistan 20032004: pp. 127-131.

Tzannatos, Zafiris. (1999). "Women and Labor Market Changes in the Global Economy: Growth Helps, Inequalities Hurt, and Public Policy Matters" World Development, 3: pp. 551-569.

Ward, Katharine. (1990). Women Workers and Global Restructuring. New York: Cornell University Press. (Introductory chapter)

Roohi Mumtaz is Research Scholar in the Department of Public Administration, University of Karachi

Dr. Syed Shabib ul Hasan is Associate Professor in the Department of Public Administration, University of Karachi.

Afsheen Nizam is Assistant Professor in the Department of Public Administration, University of Karachi

Saima Akhter is Assistant Professor in the Department of Public Administration, University of Karachi 